\title{
The protein-calorie value of British hospital meals
}

\author{
By P. L. PELLETT AND T. P. EDDY \\ Human Nutrition Department, London School of Hygiene and \\ Tropical Medicine, Keppel Street, London, WC $\mathrm{I}$ \\ (Received 28 April 1964-Accepted 6 fuly 1964)
}

The Nuffield Provincial Hospitals Trust recently published a Report Food in Hospitals (Platt, Eddy \& Pellett, I963) describing the results of a study of the nutritive value of food in a survey of 152 provincial non-teaching hospitals, with some additional investigations in hospitals in Cornwall, London and Newcastle upon Tyne.

The theoretical methods used in the prediction of protein-calorie values of the total food consumed in relation to the patients' estimated requirements have been described by Eddy \& Pellett (1964). The present paper is concerned only with analytical methods, and methods used in the determination of protein score, and hence of net dietary protein calories as a percentage of total calories ( $\mathrm{NDpCal} \%$; Platt, Miller \& Payne, 1961).

\section{EXPERIMENTAL \\ Sampling}

The method of sampling is fully described in the Report (Platt et al. 1963). The 152 hospitals were selected at random, and in each hospital the food taken by one randomly selected adult patient on a full normal diet was measured during $24 \mathrm{~h}$. Maternity patients were excluded from the survey. The age and sex distribution of selected patients has also been described in the Report; 103 of the patients were over 50 years, the age distribution being similar to that expected for the hospital population as a whole. Duplicate samples of breakfast, lunch and supper given during $24 \mathrm{~h}$ to each subject were weighed and transported in insulated containers with solid $\mathrm{CO}_{2}$ to the laboratory for analysis.

\section{Protein and energy}

\section{Analytical methods}

The meals were thawed immediately before analysis and homogenized. Duplicate samples of the homogenates were dried overnight at $105^{\circ}$ and the percentage dry weight was calculated. The dry material was ground to a powder and used for all subsequent analyses. Nitrogen was estimated by a semi-micro-Kjeldahl procedure (Association of Official Agricultural Chemists, 1960). The crude protein content of the food was calculated as $6.25 \times$ the $\mathrm{N}$ content; for the determination of percentage of calories from protein the calorific value of the protein was taken as $4 \mathrm{kcal} / \mathrm{g}$. The calorific value of the dried meals was determined with the ballistic bomb calorimeter, the gross energy so obtained being converted into metabolizable energy by the equation

$$
\mathrm{ME} / \mathrm{g}=(\mathrm{GE} / \mathrm{g} \times 0.95)-(\mathrm{N} \% \times 0.075),
$$


where $\mathrm{ME}=$ metabolizable energy and $\mathrm{GE}=$ gross energy, both in kcal, as described by Miller \& Payne (1959). Hence the protein calories as a percentage of total calories (PCal \%) were calculated:

\section{Total sulphur}

$$
\text { PCal } \%=\frac{N \% \times 25}{M E / g} .
$$

The procedure used combined the oxygen combustion technique of Lysyj \& Zarembo (1958) with a modified version of the barium chloranilate method of Bertolacini \& Barney (1957). The main modification was in the type of buffer for it was found that sodium acetate-acetic acid could be used in considerably greater concentration than could the potassium acid phthalate used by the original authors, and thus gave greater buffering capacity without inhibition of colcur production.

Apparatus. The apparatus consisted of an oxygen cylinder; twelve $500 \mathrm{ml}$ conical flasks fitted with plastic or glass stoppers each holding a glass rod and platinum wire spiral; twelve small columns for ion exchange resin $c .3$ in. $\times \frac{1}{2}$ in.; a colorimeter to read at $c .350 \mathrm{~nm}$; test tubes, stoppered, and graduated, to hold $10-15 \mathrm{ml}$; a shaker for the tubes.

Chemicals. The barium chloranilate was either purchased directly (Hopkins and Williams Ltd, Chadwell Heath, Essex) or made in the laboratory as follows.

Chloranilic acid $(51.0 \cdot 2 \%, \mathrm{w} / \mathrm{v})$ was mixed with $51.10 \%(\mathrm{w} / \mathrm{v})$ barium chloride and the mixture allowed to age for at least I day (i.e. until the initial colloidal tan precipitate had changed into a purple crystalline mater:al). The supernatant liquor was removed and the precipitate washed three times with $2 \mathrm{l}$. water, filtered, washed with ethanol and diethyl ether, allowed to dry and finally ground to a powder.

The alcoholic buffer solution was:

$\begin{array}{lr}\text { Anhydrous sodium acetate } & \text { Ic.5 } 5 \\ \text { Glacial acetic acid } & 2 \mathrm{ml} \\ \text { Deionized water } & 5^{\mathrm{c}} \mathrm{ml} \\ \text { Ethanol } & \text { to I l. }\end{array}$

The potassium sulphate standard was prepared as follows:

Anhydrous $\mathrm{K}_{2} \mathrm{SO}_{4}(\mathrm{r} \cdot 09 \circ \mathrm{g})$ was made up to $100 \mathrm{ml}$ with deionized water; this solution contained $2 \mathrm{mg} \mathrm{S} / \mathrm{ml}$. Standard solutions were made by diluting $0,2,4,6$ and $8 \mathrm{ml}$ to $200 \mathrm{ml}$; these solutions contained respectively o, 20, 40, 60 and $80 \mu \mathrm{g} \mathrm{S} / \mathrm{ml}$. Since these solutions were used diluted to twice their volumes with alcoholic buffer, the standard curve thus ranged between 0 and $40 \mu \mathrm{g} / \mathrm{ml}$.

The Dowex $50 w \times 8$ hydrogen form, 20 to 50 mesh (Dow Chemical Co. Midland,

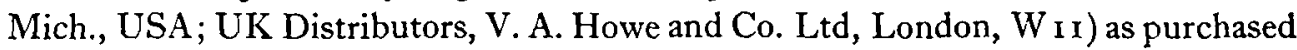
was washed free from fine powdery material before use. Regeneration was by means of washing in a column with two volumes of $\mathrm{N}-\mathrm{HCl}$ during 30 min followed by deionized water until no turbidity was produced with $0 \cdot \mathrm{I} \mathrm{N}-\mathrm{AgNO}_{3}$, i.e. the washing water was free of chloride.

Procedure. Water $(15 \mathrm{ml})$ was placed in a conical flask, followed by $2-3$ drops of 100 vol. $\mathrm{H}_{2} \mathrm{O}_{2}$ (AR) and the flask was filled with oxygen by simple displacement; 
I 50-I $80 \mathrm{mg}$ of sample were weighed in a small piece of cigarette paper, and then placed in the platinum spiral. The sample was ignited by touching the twisted paper to a small flame and plunging it into the oxygen. The samples were successively burnt and allowed to stand with occasional shaking for $\frac{1}{2} \mathrm{~h}$.

A column was prepared with Dowex 50 (about 2 in. bed depth) and was sucked dry; the liquid was poured down the column, the first $\mathrm{I}-2 \mathrm{ml}$ were rejected and the remainder collected into a graduated test tube. This sample or a similar volume of standard $\mathrm{K}_{2} \mathrm{SO}_{4}$ solution was diluted with alcoholic buffer until exactly double in volume (slightly more than an equal volume was needed since alcohol-water mixtures contract) and about $20 \mathrm{mg}$ barium chloranilate were added. The tube was stoppered, shaken for Io min and then filtered through a Whatman no. 5 or equivalent paper. The extinction was read on the colorimeter and the sulphur content calculated from a standard curve prepared in the same way with the standard $\mathrm{K}_{2} \mathrm{SO}_{4}$ solution.

The accuracy of the method was checked initially with a mixture of pure dry methionine and sucrose at a known concentration and also with sulphanilic acid, the expected $\mathrm{S}$ content being calculated from the formula and the percentage $\mathrm{N}$ found by analysis.

Six food samples, supplied by Dr D. J. Naismith of the Human Nutrition Research Unit of the Medical Research Council, which had been analysed by him using a modified benzidine sulphate procedure (Miller \& Naismith, 1958), were then analysed. The comparison is shown in Table $\mathrm{I}$. The standard errors of the means were not as small as hoped but were well within the requirements of accuracy for our purpose. Samples were normally analysed at least in triplicate since probably the main cause of inaccuracy lay in the small sample size necessitated by combustion in oxygen at atmospheric pressure.

\section{Scoring procedure}

(a) From total $S$. The formula of Miller \& Donoso ( 1963 ),

$$
\text { score }=(1000 \times \mathrm{S} \%) \div \mathrm{N} \% \text {, }
$$

was applied to the eighty-three meals analysed for total $\mathrm{S}$.

(b) From food tables by use of $S$ amino acids. This calculation was made for all meals and extras, by relating the weight of total S-containing amino acids per $\mathrm{g} N$ in each foodstuff to the reference value of $270 \mathrm{mg} / \mathrm{g} \mathrm{N}$ (FAO, I957). Proportionate weights of $\mathrm{N}$ and S-containing amino acids were calculated, by means of food tables, from the gross weights of food in each dish served to the ward at the meal. $\mathrm{N}$ values were obtained from the tables of McCance \& Widdowson (I960), and the amino acid values used (see Table 2) were selected at the Human Nutrition Research Unit of the Medical Research Council from values given by Orr \& Watt (1957) as giving the best correlation with net protein utilization, standardized $\left(\mathrm{NPU}_{(\mathrm{st})}\right)$, determined directly by animal feeding experiments. The table gave scores ranging from 40 for vegetables to more than 100 for eggs, and it was a simple calculation to give a weighted average for each meal. In practice the score of these diets, which was usually around 80, was raised to over 90 if there was an appreciable amount of egg in the food, and was reduced to 
Table I. Comparison of alternative methods of analysis for total sulphur

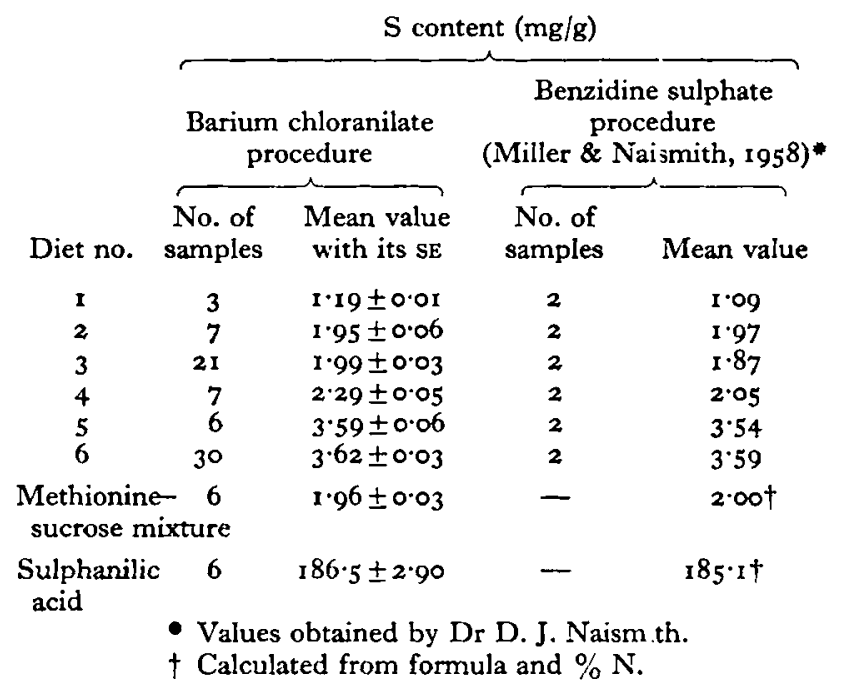

around 70 or less when legumes contributed much vegetable protein. The results obtained by the two methods of scoring for eighty-three: meals are shown in Fig. $x$. There was a fair degree of correlation between them: $r:=+0.65 \pm 0.11$ (SE).

$N D p C a l \%$. This was calculated as described by Miller \& Payne ( $196 \mathrm{x} b)$ from the protein score (obtained as described above, i.e. either frorn the $\mathrm{S}: \mathrm{N}$ ratio or from food tables) and from the $\mathrm{PCal} \%$ (from analytical results).

Table 2. Chemical scores of foodstuffs based on selected values from Amino Acid Content of Foods (Orr \& Watt, 1957)

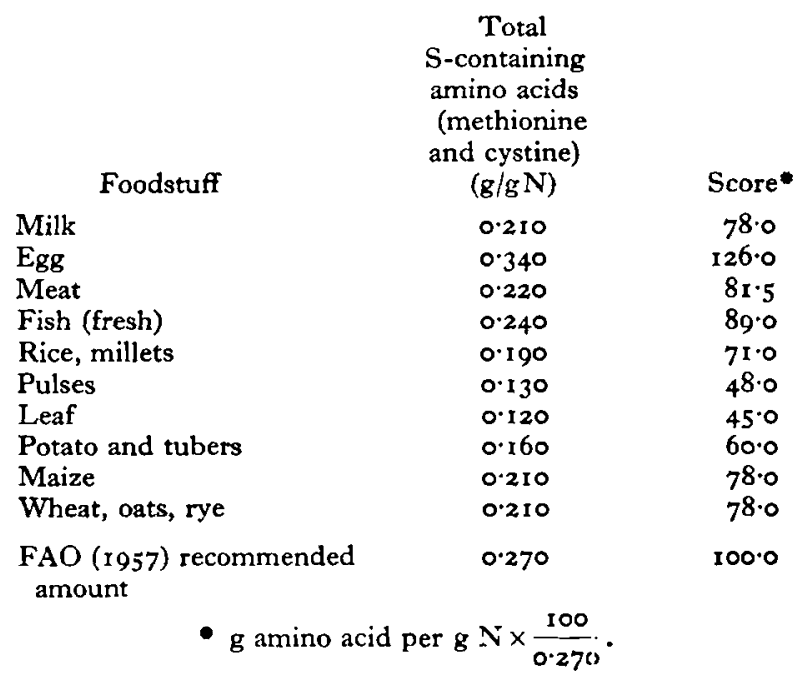




\section{RESULTS AND DISCUSSION}

The comparison between the scores predicted by the two methods is shown in Fig. I. Table 3 shows that the total S scores for eighty-three meals gave essentially the same indication of the relative qualities of the breakfast, midday and evening meals as did the $\mathrm{S}$ amino acid scores for the whole population of meals sampled and, further, that the small sample of eighty-three meals was representative of the whole. Tables 4 and 5 show the breakdown for protein scores and NDpCal \% respectively

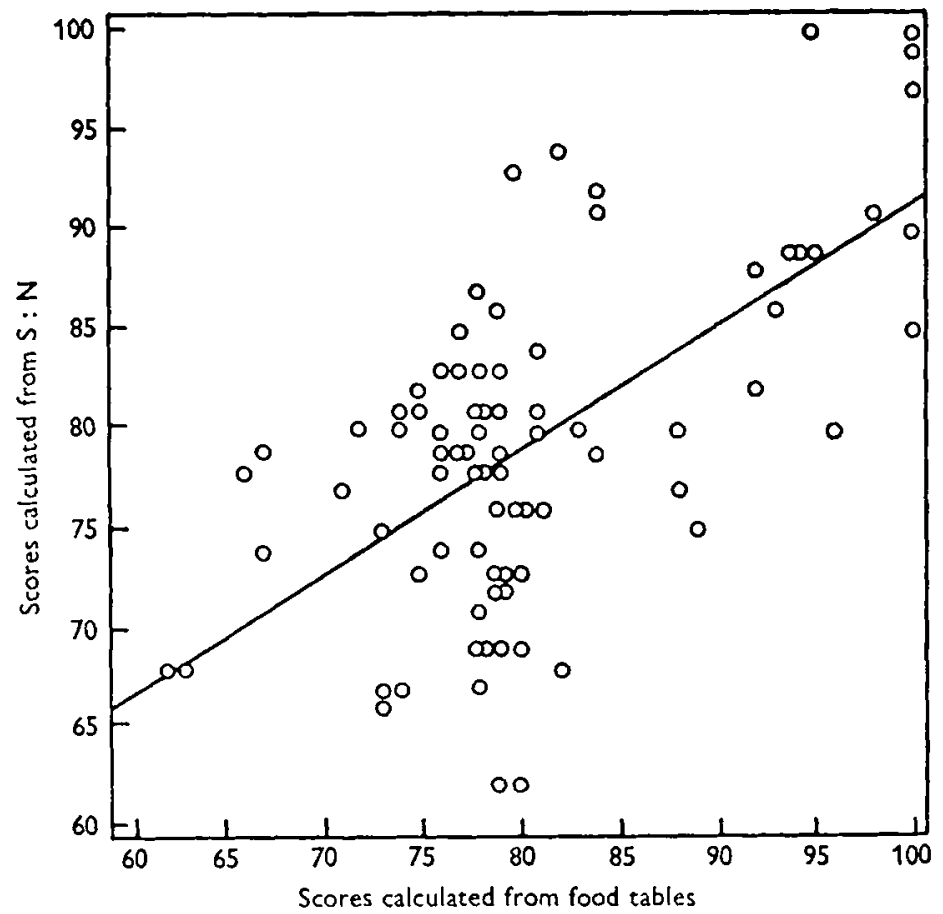

Fig. 1. Protein scores of eighty-three meals measured as ( $1000 \times \mathrm{S} \%) \div \mathrm{N} \%$ compared with scores calculated from tables of sulphur amino acid values. $r=+0.65 \pm 0.11$ (sE); $y=0.63 x+28 \cdot 9$.

with regard to meal (i.e. breakfast, midday and evening) and to type of hospital. The breakfast meal was of significantly higher $(P<0.01)$ quality (protein score) than either midday or evening meal and the midday meal was significantly lower $(P<0.01)$ in quality than the other two. However, since the total quantity of protein was highest in the midday meal and generally lowest at breakfast (Table 16 of Platt et al. 1963), the NDpCal \% was similar for all three meals. With the exception of the evening meal in mental hospitals, which was significantly lower $(P<0.01)$ than all other meals in NDpCal \% (owing to lower $\mathrm{PCal} \%$ ), the score and the NDpCal \% were similar in all classes of hospital.

At the end of the survey, there was material from over $45^{\circ}$ homogenized meals; these were classified into different types of meal for biological assay, and all meals 
Table 3. Comparison of protein scores of meals calculuted from the $S$ amino acid contents (from tables) and the total $S$ content (by analysis)

\begin{tabular}{|c|c|c|c|c|}
\hline & \multicolumn{4}{|c|}{ Score } \\
\hline & \multicolumn{2}{|c|}{$\mathrm{S}$ amino acids } & \multicolumn{2}{|c|}{ Total S } \\
\hline Meal & $\begin{array}{l}\text { No. of } \\
\text { samples }\end{array}$ & $\begin{array}{c}\text { Mean value } \\
\text { with its SB }\end{array}$ & $\begin{array}{l}\text { No. of } \\
\text { sampliss }\end{array}$ & $\begin{array}{c}\text { Mean value } \\
\text { with its SE }\end{array}$ \\
\hline Breakfast & I54 & $85.5 \pm 0.7$ & 23 & $84 \cdot 8 \pm 1 \cdot 5$ \\
\hline Midday & 152 & $76 \cdot 2 \pm 0 \cdot 3$ & 23 & $76 \cdot 3 \pm 1 \cdot 5$ \\
\hline Evening & 155 & $79.7 \pm 0.6$ & 37 & $77 \cdot 1 \pm 1 \cdot 4$ \\
\hline $\begin{array}{l}\text { All meals } \\
\text { Meals analysed } \\
\text { for total } \mathrm{S}\end{array}$ & $\begin{array}{r}461 \\
83\end{array}$ & $\begin{array}{l}80.5 \pm 0.4 \\
80.6 \pm 0.9\end{array}$ & 83 & $78 \cdot 9 \pm 0.9$ \\
\hline
\end{tabular}

Table 4. Protein scores of the three main meals analysed by type of hospital and number of beds

\begin{tabular}{|c|c|c|c|c|c|c|}
\hline \multirow[b]{2}{*}{$\begin{array}{l}\text { Type of hospital } \\
\text { and no. of beds }\end{array}$} & \multicolumn{2}{|c|}{ Breakfast } & \multicolumn{2}{|c|}{ Midday meal } & \multicolumn{2}{|c|}{ Evening meal } \\
\hline & $\begin{array}{l}\text { No. of } \\
\text { samples }\end{array}$ & $\begin{array}{l}\text { Mean value } \\
\text { with its } \mathrm{SE}\end{array}$ & $\begin{array}{l}\text { No. of } \\
\text { samples }\end{array}$ & $\begin{array}{l}\text { Mean ralue } \\
\text { with it } ; S E\end{array}$ & $\begin{array}{c}\text { No. of } \\
\text { samples }\end{array}$ & $\begin{array}{l}\text { Mean value } \\
\text { with its SE }\end{array}$ \\
\hline Acute: $\begin{aligned} 0-100 \\
\\
101-300 \\
300+\end{aligned}$ & $\begin{array}{l}46 \\
36 \\
20\end{array}$ & $\begin{array}{l}86 \cdot 7 \pm 1 \cdot 4 \\
84 \cdot 7 \pm 1 \cdot 5 \\
87 \cdot 5 \pm 1 \cdot 8\end{array}$ & $\begin{array}{l}46 \\
36 \\
19\end{array}$ & $\begin{array}{l}77 \cdot 0 \pm 0.6 \\
75 \cdot 3 \pm 1 \cdot 0 \\
75 \cdot 1 \pm 1 \cdot 2\end{array}$ & $\begin{array}{l}46 \\
36 \\
20\end{array}$ & $\begin{array}{l}80 \cdot \pm \pm 1 \cdot 2 \\
78 \cdot 4 \pm 1 \cdot 4 \\
78 \cdot 5 \pm 0.9\end{array}$ \\
\hline Total & 102 & $86.1 \pm 0.9$ & 101 & $76.0 \pm 0.4$ & 102 & $79.3 \pm 0.8$ \\
\hline Chronic: $\begin{aligned} & 0-100 \\
& 101-300\end{aligned}$ & $\begin{array}{l}16 \\
0 \quad 15\end{array}$ & $\begin{array}{l}84 \cdot 5 \pm 2 \cdot 6 \\
84 \cdot 0 \pm 3 \cdot 0\end{array}$ & $\begin{array}{l}14 \\
16\end{array}$ & $\begin{array}{l}76.5 \pm 0.9 \\
76.0 \pm 0.8\end{array}$ & $\begin{array}{l}16 \\
16\end{array}$ & $\begin{array}{l}8 \mathrm{I} \cdot \mathrm{I} \pm \mathrm{x} \cdot 4 \\
82 \cdot 7 \pm I \cdot 9\end{array}$ \\
\hline Total & $3^{I}$ & $84 \cdot 3 \pm 1 \cdot 8$ & 30 & $76 \cdot 2 \pm 0.5$ & 32 & $81 \cdot 9 \pm 1 \cdot 2$ \\
\hline Mental & $2 \mathrm{I}$ & $84 \cdot 2 \pm I \cdot 9$ & 21 & $76.8 \pm 0.8$ & 21 & $78 \cdot 5 \pm 0.9$ \\
\hline $\begin{array}{l}\text { Total, all } \\
\text { hospitals }\end{array}$ & 154 & $85.5 \pm 0.7$ & I 52 & $76 \cdot 2 \pm 0.3$ & 155 & $79.7 \pm 0.6$ \\
\hline
\end{tabular}

Table 5. NDPCal \% of the three main meals analysed by type of hospital and number of beds

\begin{tabular}{|c|c|c|c|c|c|c|}
\hline \multirow[b]{2}{*}{$\begin{array}{l}\text { Type of hospital } \\
\text { and no. of beds }\end{array}$} & \multicolumn{2}{|c|}{ Breakfast } & \multicolumn{2}{|c|}{ Midday meal } & \multicolumn{2}{|c|}{ Evening meal } \\
\hline & $\begin{array}{c}\text { No. of } \\
\text { samples }\end{array}$ & $\begin{array}{c}\text { Mean value } \\
\text { with its SE }\end{array}$ & $\begin{array}{c}\text { No. of } \\
\text { samples }\end{array}$ & $\begin{array}{l}\text { Mean value } \\
\text { with ts SE }\end{array}$ & $\begin{array}{l}\text { No. of } \\
\text { samples }\end{array}$ & $\begin{array}{c}\text { Mean value } \\
\text { with its SE }\end{array}$ \\
\hline Acute: $\begin{aligned} & 0-100 \\
& 101-300 \\
& 300+\end{aligned}$ & $\begin{array}{l}46 \\
36 \\
20\end{array}$ & $\begin{array}{r}9.8 \pm 0.29 \\
10.0 \pm 0.28 \\
9.6 \pm 0.52\end{array}$ & $\begin{array}{l}46 \\
36 \\
19\end{array}$ & $\begin{array}{l}9.7 \pm 0.18 \\
9.7 \pm 0.26 \\
9.5 \pm 0.34\end{array}$ & $\begin{array}{l}46 \\
36 \\
20\end{array}$ & $\begin{array}{r}10 \cdot 0 \pm 0.23 \\
9 \cdot 6 \pm 0.32 \\
9.7 \pm 0.31\end{array}$ \\
\hline Total & 102 & $9.8 \pm 0.20$ & ror & $9.7 \pm 0.13$ & 102 & $9.8 \pm 0.15$ \\
\hline $\begin{aligned} \text { Chronic: } & 0-100 \\
& 101-300\end{aligned}$ & $\begin{array}{l}16 \\
15\end{array}$ & $\begin{array}{l}9.4 \pm 0.58 \\
9.8 \pm 0.78\end{array}$ & $\begin{array}{l}14 \\
16\end{array}$ & $\begin{array}{l}9.4 \pm 0.37 \\
9.2 \pm 0.37\end{array}$ & $\begin{array}{l}16 \\
16\end{array}$ & $\begin{array}{r}9.5 \pm 0.45 \\
10.1 \pm 0.38\end{array}$ \\
\hline Total & 31 & $9 \cdot 6 \pm 0.36$ & 30 & $9.3 \pm 0.27$ & 32 & $9.8 \pm 0.30$ \\
\hline Mental & $2 \mathrm{I}$ & $9.4 \pm 0.35$ & 21 & $9.3 \pm 0.29$ & 21 & $7 \cdot 9 \pm 0.28$ \\
\hline $\begin{array}{c}\text { Total, all } \\
\text { hospitals }\end{array}$ & 154 & $9.7 \pm 0.15$ & 152 & $9 \cdot 6 \pm 0 \cdot 11$ & 155 & $9.5 \pm 0.14$ \\
\hline
\end{tabular}


within each class were mixed together to form nineteen bulked meals of different types. The bulked meals each weighed approximately $5 \mathrm{~kg}$ and were derived from fifteen to sixty separate meals. The net protein utilization, operative $\left(\mathrm{NPU}_{(\mathrm{op})}\right)$, of the bulked diets was determined by rat feeding experiments (Miller \& Bender, 1955; Miller \& Payne, I $196 \mathrm{I} a$ ) and the NDpCal \% was calculated from the equation NDpCal \% = $\mathrm{NPU}_{(\mathrm{op})} \times \mathrm{PCal} \%$. Details of the classification of meals and of these calculations are shown in Table 6.

Table 6. Comparison of methods used for scoring protein and predicting protein values with the biological assay of bulked meals

\begin{tabular}{|c|c|c|c|c|c|c|c|c|c|}
\hline \multirow[b]{2}{*}{$\begin{array}{l}\text { Classification } \\
\text { of foodstuff }\end{array}$} & \multirow[b]{2}{*}{$\begin{array}{l}\mathrm{PCal} \\
\%\end{array}$} & \multicolumn{2}{|c|}{$\begin{array}{c}\text { Determined by } \\
\text { biological } \\
\text { assay }\end{array}$} & \multicolumn{3}{|c|}{$\begin{array}{l}\text { Calculated from } \\
\text { 1000 } \times \frac{\mathrm{S} \%}{\mathrm{~N} \%}\end{array}$} & \multicolumn{3}{|c|}{$\begin{array}{l}\text { Calculated from } \\
\mathrm{S} \text { amino acid contents }\end{array}$} \\
\hline & & $\mathrm{NPU}_{(\mathrm{Op})}$ & $\begin{array}{l}\text { Nop } \\
\text { Cal \% }\end{array}$ & Score & $\mathrm{NPU}_{(0 p)}$ & $\begin{array}{l}\text { NDp } \\
\text { Cal \% }\end{array}$ & Score & $N P U_{(o p)}$ & $\begin{array}{c}\text { Nop } \\
\text { Cal \% }\end{array}$ \\
\hline $\begin{array}{l}\text { flour, vegetables, no } \\
\text { me }\end{array}$ & I $5 \cdot 3$ & 55 & $8 \cdot 4$ & 79 & 62 & 9.5 & 77 & $6 \mathrm{I}$ & $9 \cdot 3$ \\
\hline o legume & 13.7 & 56 & $7 \cdot 7$ & 81 & 66 & $9 \cdot 3$ & 83 & 67 & $9 \cdot 4$ \\
\hline $\begin{array}{l}\text { vegetables, milk } \\
\text { ding, no legume }\end{array}$ & $18 \cdot 7$ & 55 & $10 \cdot 3$ & 77 & 56 & 103 & 75 & 54 & $10 \cdot 2$ \\
\hline vegetables, flour, no & $16 \cdot 0$ & 55 & $8 \cdot 8$ & 76 & 58 & $9 \cdot 4$ & 77 & 60 & $9 \cdot 6$ \\
\hline ge, flour, meat & $14 \cdot 3$ & 63 & $9 \cdot 0$ & 86 & 69 & $10 \cdot 0$ & 79 & 63 & $9 \cdot 2$ \\
\hline legume & $19 \cdot 7$ & 59 & II 6 & $8 \mathrm{I}$ & 57 & $\mathbf{I} \mathbf{I} \cdot \mathbf{I}$ & 79 & 55 & 10.9 \\
\hline + Hour (sandwich) & $18 \cdot 4$ & 56 & $10 \cdot 3$ & 74 & 54 & $10 \cdot 0$ & 79 & 57 & 10.5 \\
\hline+ legume & $18 \cdot 4$ & 55 & IO. I & 72 & 53 & $9 \cdot 8$ & 74 & 54 & $9 \cdot 9$ \\
\hline $\begin{array}{l}\text { ges, rissoles + legume } \\
\text { egg }\end{array}$ & $\begin{array}{l}17.0 \\
17.6\end{array}$ & $\begin{array}{l}51 \\
58\end{array}$ & $\begin{array}{r}8 \cdot 7 \\
10 \cdot 2\end{array}$ & $\begin{array}{l}75 \\
84\end{array}$ & $\begin{array}{l}57 \\
62\end{array}$ & $\begin{array}{r}9.5 \\
10.8\end{array}$ & $\begin{array}{l}71 \\
91\end{array}$ & $\begin{array}{l}54 \\
67\end{array}$ & $\begin{array}{r}9 \cdot 2 \\
11 \cdot 7\end{array}$ \\
\hline $\begin{array}{l}\text { lge, egg } \\
\text { lakes, flour and egg }\end{array}$ & $\begin{array}{l}15 \cdot 6 \\
15 \cdot 6\end{array}$ & $\begin{array}{l}71 \\
66\end{array}$ & $\begin{array}{l}12 \cdot 1 \\
10 \cdot 3\end{array}$ & $\begin{array}{l}97 \\
87\end{array}$ & $\begin{array}{l}75 \\
67\end{array}$ & $\begin{array}{r}115 \\
9 \cdot 8\end{array}$ & $\begin{array}{l}97 \\
98\end{array}$ & $\begin{array}{l}75 \\
76\end{array}$ & $\begin{array}{ll}11 \cdot 6 \\
11 \cdot 8\end{array}$ \\
\hline $\begin{array}{l}\text { vegetables } \\
\text { lakes, porridge, flour } \\
\text { meat }\end{array}$ & $\begin{array}{l}15 \cdot 6 \\
13.5\end{array}$ & $\begin{array}{l}71 \\
65\end{array}$ & $\begin{array}{r}1 Y \cdot 1 \\
8 \cdot 8\end{array}$ & $\begin{array}{l}91 \\
78\end{array}$ & $\begin{array}{l}71 \\
64\end{array}$ & $\begin{array}{r}10.9 \\
8.7\end{array}$ & $\begin{array}{l}94 \\
79\end{array}$ & $\begin{array}{l}73 \\
65\end{array}$ & $\begin{array}{r}\mathrm{II} \cdot 3 \\
8 \cdot 9\end{array}$ \\
\hline and vegetable protein & $14 \cdot 4$ & 62 & $8 \cdot 9$ & 81 & 65 & $9 \cdot 5$ & 78 & 63 & $9 \cdot 1$ \\
\hline and vegetables & I I 9 & 64 & $7 \cdot 6$ & 83 & 71 & $8 \cdot 3$ & 78 & 66 & $7 \cdot 9$ \\
\hline vegetables, milk & $19 \cdot 7$ & 56 & II.O & 83 & 57 & $11 \cdot 4$ & 75 & 53 & 10.4 \\
\hline flour, vegetables, milk & $16 \cdot 6$ & 59 & $9 \cdot 8$ & 79 & 60 & 9.9 & 77 & 59 & $9 \cdot 8$ \\
\hline vegetables, no legume & $21 \cdot 5$ & 52 & $1 I \cdot 2$ & 78 & 52 & II.I & 73 & 49 & 10.5 \\
\hline
\end{tabular}

\section{Coefficients of correlation}

(a) Between $\mathrm{NPL}_{i 0 \mathrm{p})}$ measured biologically and $\mathrm{NPU}(\mathrm{Op})$ calculated from $\mathrm{S}: \mathrm{N}$ ratio: $r=0.86$

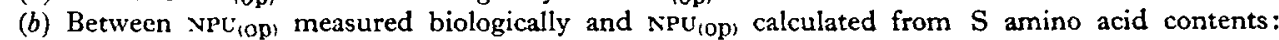
$r=0.84$

(c) Between vopCal \% measured biologically and NopCal \% calculated from S:N ratio: $r=0.8 \mathrm{~g}$

(d) Between NopCal \% measured biologically and sppCal \% calculated from $\mathrm{S}$ amino acid contents: $r=0.83$

(e) Between score calculated from $S: N$ ratio and calculated from $S$ amino acid contents: $r=0.75$

Both methods of scoring (i.e. $\mathrm{S}: \mathrm{N}$ ratio and $\mathrm{S}$ amino acid values) were applied to the nineteen bulked meals. From the scores so obtained, protein values for the meals were predicted and compared with the values determined by biological assay. The correlation coefficients between protein values $\left(\mathrm{NPU}_{(\mathrm{op})}\right.$ and $\mathrm{NDpCal} \%$ ) determined by biological assay and the predicted values based on the two methods of scoring were 
all high and ranged between $r=0.83$ and $r=0.89$. It appears that prediction of protein values as NDpCal \% based upon a protein score estimated by either method can be used to make a reliable estimate of mixed meals, similar to those listed in Table 6 , in this type of survey.

\section{SUMMARY}

r. The paper gives information on the protein quality of hospital food collected during a survey of hospital food sponsored by the Nuffield I'rovincial Hospitals 'Trust.

2. In all, 152 hospitals were selected at random and in each the food taken at the three main meals of a randomly selected adult patient on full normal diet was collected and analysed.

3. Analytical methods are described, especially a modified rapid method for measurement of total sulphur in foodstuffs and its application in estimating the protein score of a diet. Comparison is made between protein scores calculated from food tables and those calculated from the $\mathrm{S}: \mathrm{N}$ ratio for eighty-three meals.

4. Protein scores and NDpCal \% were calculated for sorne $45^{\circ}$ hospital meals and are classified by type of meal and size and type of hospital.

5. Nineteen mixed meals were obtained by bulking together meals of similar composition; they were freeze-dried, and given to rats to obtain the $\mathrm{NPU}_{(\mathrm{op})}$. Comparison was made between biological assay and two scoririg procedures.

6. Evidence is presented that prediction of protein values as NDpCal \% based upon a protein score estimated by either method can be used to make a reliable estimate of mixed meals, similar to those listed, in this type of survey.

\section{REFERENCES}

Association of Official Agricultural Chemists ( 1960$)$. Official Methods of Analysis, gth ed. Washington, DC: Association of Official Agricultural Chemists.

Bertolacini, R. J. \& Barncy, J. E. II (1957). Analyt. Chem. 29, 281.

Eddy, T. P. \& Pellett, P. L. (1964). Brit. F. Nutr. 18, 555.

FAO (1957). F.A.O. nutr. Stud. no. I6.

Lysyj, I. \& Zarembo, J. E. (1958). Analyt. Chem. 3o, 428.

McCance, R. A. \& Widdowson, E. M. (1960). Spec. Rep. Ser. med. Res. Coun., Lond., no. 297.

Miller, D. S. \& Bender, A. E. (1955). Brit. F. Nutr. 9, 382.

Miller, D. S. \& Donoso, G. (1 963). F. Sci. Fd Agric. 14, 345.

Miller, D. S. \& Naismith, D. J. (1958). Nature, Lond., 182, 1786.

Miller, D. S. \& Payne, P. R. (1959). Brit. F. Nutr. 13, 50 1.

Miller, D. S. \& Payne, P. R. (196ra). Brit. F. Nutr. r5, I I.

Miller, D. S. \& Payne, P. R. (1961 b). F. Nutr. 74, 413 .

Ort, M. L. \& Watt, B. K. (1957). Home Econ. Res. Rep., no. 4. Amino Acid Content of Foods. U.S. Department of Agriculture, Washington, DC.

Platt, B. S., Eddy, T. P. \& Pellett, P. L. (1963). Food in Hospitals. I ondon: Oxford University Press, for Nuffield Provincial Hospitals Trust.

Platt, B. S., Miller, D. S. \& Payne, P. R. (1961). In Recent Advances in Human Nutrition, p. 35 I. [J. F. Brock, editor.] Isondon: Churchill. 